\title{
Genome analysis of Mexican flora
}

\author{
Guadalupe Palomino \\ Laboratorio de Citogenética, Jardín Botánico, Instituto de Biología, Universidad Nacional Autónoma de México, Apartado \\ Postal 70614, México, D.F. 04510, México.Fax: +5-5622-9046. E-mail: hasbach@servidor.unam.mx
}

\section{DIVERSITY OF THE MEXICAN FLORA}

Mexico can be considered to be the fourth country in the world according to its floristic and faunistic diversity (Rzedowski, 1991), this diversity being the result of the wide variation in, and combinations between physiographic, geological and climatic conditions that characterize the country. This great species richness and the high level of species endemicity are of great scientific and economic value, as has been discussed by Rzedowski (1998), who points out the existence of approximately 220 families, 2,410 genera, and 22,000 species of fanerogamic flora, and an endemicity of $10 \%$ for genera, and $52 \%$ for species. Endemicity is greatest in xerophilous shrub and grassland flora, but is also abundant, within the species category, in other vegetation types (Rzedowski, 1998).

As regards the species useful to man, Mexico is part of the origin and diversification center of Zea mays, Phaseolus vulgaris, Capsicum annuum, Gossypium hirsutum, Agave sisalana, Carica papaya, Spondia spp., Lycopersicon esculentum, and Cucurbita spp., among others (Zohary, 1970). There are between 5,000 to 7,000 useful plant species in the country, of which about 1,000 to 1,500 are edible, which shows the wide spectrum of phytogenetic resources with potential value (Caballero, 1994). It is important to point out that the diversification centers of various species are located in different areas of the country.

\section{IMPORTANCE OF GENOME CHARACTERIZATION}

For individual or groups of plants genetic variation and its causes can be investigated by cytogenetic studies which include both mitotic and meiotic chromosome analysis. Mitosis can be observed in somatic cells taken from meristematic tissue treated with mitostatic agents, fixatives and dyes (Palomino and Vázquez, 1991) and the somatic chromosome number (2n), chromosome structure (or karyotype), and polyploidy status obtained. From this information the basic number of genetic linkage groups (x) can be determined, as well as how often they are repeated, providing a rapid indicator of the genetic similarity between populations or species. This information is essential to determine the plasticity of the genotypes, between and within the different portions of the ecological range where the species are located, and is also useful to recognize the poly- ploidy level. The numeric and structural variation of karyotypes in populations of the same species (cytotypes) can also be analyzed by this type of study, and data obtained which can be useful in understanding the role of chromosomal rearrangement in plant evolution and speciation. Another useful study is the analysis of the meiotic chromosomes of pollen mother cells (PMC) contained in the immature flower anthers, in which the haploid chromosome number (n) and chromosome complement of a particular species can be observed, or the basic chromosome number (x) of a plant group corroborated. The number and position of chiasmata observed during metaphase I (MI) in bivalents (II) determine the recombination level between individual genomes (recombination index RI), and the degree of gene segregation in the next generation. With these analyses, it is possible to determine the heterozygous structural changes produced by chromosome inversions, exchanges, or fusions that alter the cross-over position and the genetic constitution of gametes (Lacadena, 1988; Russell, 1992). These analyses are useful to the taxonomist and to the evolutionary biologist because they enable them to detect differences between taxa and to recognize divergence patterns, but they also serve the plant-improvement specialist in the manipulation of genotypes in order to select high-yield species (Kenton, 1986; Lacadena, 1988).

\section{CYTOGENETIC STUDIES IN MEXICAN PLANTS: CASE STUDY}

Our main research activity in the cytogenetics laboratory at the Botanical Garden IBUNAM is directed towards the characterization of genotypes of species of various families of the Mexican flora, selected for their evolutionary, bio-systematic, ecological, and current or potential economical interest, and some studies are also conducted on endangered species. During the genome analysis of populations of various species of Salvia subgenus Calosphace (Lamiaceae) distributed throughout Mexico, we found great karyotype and ploidy pattern variation in various sections of this subgenus (Palomino et al., 1986) and B chromosomes in one species (Mercado et al., 1989). In Datura (Solanaceae) we observed variations in the genome structure of species belonging to different sections (Palomino et al., 1988a). Through the genome analysis of various species of Sophora (Leguminosae) and the integration of this 
data with morphological, palynological, and biochemical studies, these species were taxonomically relocated to the genus Sophora and Styphnolobium (Palomino et al., 1993). By studing the genome of Chenopodium (Chenopodiaceae) species, along with morphological, anatomical and chemical analyses, we relocated some of the species of this genus to the genus Teloxys (Palomino et al., 1990). In the genus Nyctocereus (Cactaceae) we noticed inter- and intraspecific variations, regardless of the homogenous condition of its species genomes (Palomino et al., 1988b).

In Crotalaria we determined inter-specific genome variation due to chromosomal rearrangements and ploidy in some species. We also observed cytotypes in $C$. incana (Palomino and Vázquez, 1991). In Gibasis schiedeana (Tradescantieae-Commelinaceae), we discovered an autotetraplode cytotype resulting from chromosome interchange and chromatid exchange (Martínez and Palomino, 1997). In Myrtillocactus geometrizans (garambullo), a cactus of commercial value, we observed the cytotypes and determined which offered greater genetic variability for subsequent use in plant-improvement programs (Cid and Palomino, 1997).

\section{DNA content}

Angiosperms possess a wide range of nuclear DNA content that differ by more that 600 times, with a variation of 1C $=0.2-127.4 \mathrm{pg}$ (Bennett et al., 1982; Bennett and Leitch, 1995, 1997), showing great diversity even among genera and species of the same family. There are many examples of inter- and intra-specific variation in DNA content per genome, independently of the ploidy level (Bennett et al., 1982; Bennett and Leitch, 1995, 1997), but such variation is not correlated with the evolutionary complexity of the species or taxonomic groups.

Variations in DNA content mainly involve repetitive DNA sequences that do not code functions. Changes in DNA content between plants of the same species with the same ploidy level are due to duplications of part of their genomes and to the "nucleotypic effect" which is defined as the effect that the DNA has on the phenotype, an effect which influences the development of different cellular parameters, such as chromosome size, cellular and nuclear volume, and mitotic and meiotic cycle duration. Natural selection affects some of these characteristics and influences the inter- and intra-specific patterns of the DNA content, as well as the plant's ecological adaptation. This means that nucleotypic effects on DNA variation are predictable and, apparently, of adaptive significance for the plants (Price, 1988).

While checking the genome size of 271 species of annual and perennial plants, Bennett (1972) found specific variations among them and related these variations to their life cycles. Intra-specific variations in the DNA content have been demonstrated in many species, e.g., in 2 annual species of Microseris: M. biguelovii, where variation was about
20\% (Price et al., 1981a), and M. douglasii, with 14\% variation (Price et al., 1981b); this type of genome selection is seemingly due to extreme environmental conditions.

DNA nuclear content in plants is commonly determined by scanning microphotometry with Feulgen dye in meristematic tissue, with other methods including biochemical extraction from a known (or estimated) number of cells and flow cytometry of isolated nuclei from foliar tissue. In our laboratory we obtained the DNA content of various species by scanning microphotometry and, recently, by flow cytometry (Dolezel, 1997).

In our laboratory we have conducted research on the genus Echeandia, including species of evolutionary interest, as well as on taxa of Leucaena considered as phytogenetic resources, and on Mammillaria san-angelensis, an endangered species.

\section{Cytotypes in Echeandia (Liliaceae) species}

Echeandia Ort. include about 90 perennial herbaceous species distributed from the Southwest of the USA to South America; 60 have been described in Mexico and Central America and many of them are endemic to this area (Cruden, 1987, 1993, 1994). Mexico is considered the origin and distribution center of the genus (Cruden, R.W., personal communication). These plants are found in pine and pineoak forests, in grasslands, xerophilous vegetation and disturbed areas.

We analyzed 33 populations of 8 species: Echeandia echeandioides, E. hintonii, E. mexicana, E. michoacensis, E. montealbanensis, E. nana, E. pubescens and E. reflexa, and found that all of them were diploid with $2 n=16, n=8$. The genus is monobasic with $\mathrm{x}=8$ chromosomes (Martínez and Palomino, 1996). Each species presented a distinctive karyotype that varied among populations of the same species. Karyotype variation at inter- and intra-specific level is the result of several processes including translocations, (heteromorphic bivalent and quadrivalent in metaphase I (MI) of meiosis) and chromatid interchanges (U type) along with subchromatid aberrations (SAB type) and heterozygotic deletions evidenced in anaphase I (AI). Nine populations of $E$. nana showed only 2 cytotypes, one of them $(1 \mathrm{st}$ cytotype $=6 \mathrm{~m}+8 \mathrm{sm}+2 \mathrm{st})$ was present in 5 populations located in the eastern portion of the Pachuca mountain range. The other 4 populations located on the western portion of the Pachuca mountain range showed a different cytotype ( $2 \mathrm{nd}$ cytotype $=10 \mathrm{~m}+8 \mathrm{sm}$ ), and we thus suppose that the Pachuca mountain range is a geographical barrier that has isolated the E. nana populations producing this intra-specific variation and favoring the appearance of the 2 cytotypes, a condition that is corroborated by the genome size variation of the two cytotypes. Inter-specific (in 8 species of Echeandia) and intra-specific variations observed in the cytotypes of this species are related to genome size variation (nuclear DNA content in pg).

The inter-specific variation in the karyotype of these 
species and the intra-specific variation shown by the karyotypes are produced by the same variation pattern that mainly corresponds to chromosomal rearrangements such as spontaneous translocations, interchanges and heterozygotic deletions that have been important in chromosomal evolution of the Echeandia species (Palomino and Martínez, 1994; Martínez and Palomino, 1996).

\section{Genome size variation in some taxa of Leucaena (Mimosoideae-Leguminosae)}

Leucaena is an American tropical and subtropical tree and shrub genus with its diversity center located in Mexico. Some taxa of Leucaena are important phytogenetic resources and are included in the traditional diet in certain parts of Mexico, while in other parts of the world they provide forage and mulch and are used to fix nitrogen in agricultural soils. Opinions vary about the total number of species and subspecies of Leucaena but Zárate (1994) recognizes 14 species and 18 subspecies in Mexico.

On analysis of 20 populations of seven taxa of Leucaena, four turned out to be consistently diploid with $2 \mathrm{n}=56$ : $L$. diversifolia subsp. diversifolia, $L$. $d$. subsp. stenocarpa, L. lanceolata subsp. lanceolata and $L$. l. subsp. sousae, while two were tetraploid with $2 \mathrm{n}=112, L$. confertiflora subsp. adenotheloidea and L. esculenta subsp. paniculata. One taxon, L. esculenta subsp. esculenta, showed both polyploidy levels.

The lowest DNA content in the diploid plants was $1.28 \mathrm{pg}$ for L. esculenta subsp. esculenta and the maximal was 1.81 for L. diversifolia subsp. diversifolia, with a variation of $25 \%$ in the DNA content of the diploid taxa. In the studied tetraploids, the lowest value was $2.66 \mathrm{pg}$ in L. esculenta subsp. paniculata and the highest was 3.31 pg for L. confertiflora subsp. adenotheloidea, resulting in a difference of $20 \%$ between the DNA content among tetraploid taxa.

The DNA content mean in the diploid taxa showed a significant difference $(\mathrm{P}<0.05)$ only between $L$. diversifolia subsp. diversifolia (1.81 pg) and L. esculenta subsp. esculenta (1.35 pg). However, there was no significant difference in the genome size between subspecies pairs as can be noted in L. diversifolia subsp. diversifolia (1.81 $\mathrm{pg})$ and $L . d$. subsp. stenocarpa $(1.49 \mathrm{pg})$ and in L. lanceolata subsp. lanceolata (1.46 pg) and L. l. subsp. sousae (1.66 pg).

In the tetraploid taxa of Leucaena that we analyzed we only observed variations $(\mathrm{P}<0.05)$ between the genomes of $L$. confertiflora subsp. adenotheloidea $(3.31 \mathrm{pg})$ and $L$. esculenta subsp. paniculata $(2.66 \mathrm{pg})$. The content in the tetraploid taxa was double in relation with those obtained in the diploid taxa, which suggests that the Leucaena tetraploid taxa are of recent origin, and have not yet been through a genome reduction process (Grant, 1976). Polyploidy does not seem to be a domestication instrument in Leucaena taxa because there are polyploids in wild forms (L. esculenta subsp. paniculata) as well as in cultivated forms (L. confertiflora subsp. adenotheloidea; Palomino et al., 1995).

Ploidy stability control by flow cytometry in

Mammillaria san-angelensis (Cactaceae) propagated by in vitro culture

M. san-angelensis is an endangered species endemic to the Valley of Mexico. At the Botanical Garden-IBUNAM, research has been underway for several years with the aim of re-introducing this species to its environment through a program based on massive propagation using in vitro cultures (Rubluo et al., 1993). As extended subculture induces genetic instability, mainly due to chromosomal abnormalities, the objective of these experiments has been, among others, to analyze the genetic stability of in vitro derived regenerants, evaluating their karyotypes, nuclear DNA content, ploidy level, and endoploidy. Specimens are grown in an MS (Murashige and Skoog, 1962) basal medium enhanced with $0.1 \mathrm{ml} \mathrm{BA}$ (benzyl amino purine) as explant source and subcultured every 4 months for 7 years in MS basal medium. The in vitro regenerated plantlets of the first generation were grown in a greenhouse and used as controls. In these plants, the karyotypes were analyzed using radicular meristems. The meiotic chromosomes in pollen mother cells (PMC), the DNA content and the ploidy level were determined using a Partec CA II flow cytometer, for which the parenchyma nuclei of $M$. san-angelensis were isolated by the Otto procedure and dyed with propidium iodide (PI). Lycopersicon esculentum cv. "Stupické polní rané", 2C = 1.96 pg DNA (Dolezel et al., 1992), was used as an internal standard. Control and regenerated plantlets were diploid $(2 n=22, n=11)$, and did not show chromosomal abnormalities in MI, AI and AII. The DNA content in all regenerants and in control plants corresponded to 3.20 $\mathrm{pg}$ and an endoploidy pattern was observed in both groups of plants, corresponding to cells $2 \mathrm{C}, 4 \mathrm{C}, 8 \mathrm{C}$ and $16 \mathrm{C}$ with percentages of 48,30,17 and 5\%, respectively. Our results show that genome stability is related to the genetic constitution of the control plants, which remained constant regardless of the prolonged in vitro subculture of $M$. sanangelensis. This fact is important in plants propagated in vitro that are re-introduced into nature (Palomino et al., 1999) and in the future genome stability in plants produced by extended subculture of $M$. san-angelensis will be supported by repetitive DNA sequence studies (RAPD’S).

\section{CONCLUDING REMARKS}

Cytogenetic studies of Mexican plants, integrated with studies from other areas such as taxonomy, ethnobotany, palynology, reproductive biology, biochemistry and bromatology, will form the basis for the bio-systematic study of these plants. Such studies will contribute to the general knowledge of Mexican flora and may include the preparation of monographs, the investigation of regional 
flora, the assessment of current and/or potential phytogenetic resources and endangered species recovery (Palomino, 1991).

\section{ACKNOWLEDGMENTS}

Research partially financed by OEA: Citogenética 88-89, PRDCyT, by CONACyT and by IAEA: Mex/5/023.

\section{REFERENCES}

Bennett, M.D. (1972). Nuclear DNA content and minimum generation time in herbaceous plants. Proc. R. Soc. Lond. Ser. B. 181: 109-135.

Bennett, M.D. and Leitch, I.J. (1995). Nuclear DNA amounts in angiosperms. Ann. Bot. 76: 113-176.

Bennett, M.D. and Leitch, I.J. (1997). Nuclear DNA amounts in angiosperms583 new estimates. Ann. Bot. 80: 169-196.

Bennett, M.D., Smith J.B. and Harrison, J.S. (1982). Nuclear DNA amounts in angiosperms. Proc. R. Soc. Lond. Ser. B. 216: 179-199.

Caballero, J. (1994). La dimension culturelle de la diversité végétale au Mexique. J. Agric. Tradit. Bot. Appl. (Nouvelle série). XXXVI: 145-158.

Cid, R. and Palomino, G. (1997). Cytotypes and meiotic behavior in Mexican populations of Myrtyllocactus geometrizans var. geometrizans (Cactaceae). Cytologia 61:343-348.

Cruden, R.W. (1987). New species of Echeandia (Liliaceae) from Nueva Galicia. Contrib. Univ. Mich. Herb. 16: 129-133.

Cruden, R.W. (1993). New species of Echeandia (Liliaceae) from Oaxaca, Mexico. Phytologia 74: 128-137.

Cruden, R.W. (1994). 3. Echeandia Ortega. In: Flora Mesoamericana, Alismataceae a Cyperaceae (Davidse, G., Sousa, M.S. and Charter, A.O., eds.). Vol. 6. Instituto de Biología, Univ. Nal. Autón., Mexico, pp. 27-30.

Dolezel, J. (1997). Applications of flow cytometry for study of plant genomes. J. Appl. Genet. 38: 285-302.

Dolezel, J., Sgorbati, S. and Lucretti, S. (1992). Comparison of three DNA fluorochromes for flow cytometric estimation of nuclear DNA content in plants. Physiol. Plant. 85: 625-631.

Grant, W.F. (1976). The evolution of karyotype and polyploidy level in arboreal plants. Taxon 25: 75-84

Kenton, A. (1986). Importancia de los cromosomas en la especiación and evolución como base para el conocimiento and caracterización de especies vegetales con valor potencial. In: II Seminario Maximino Martínez, 1986. La aplicación de la Citogenética en el conocimiento biológico de los recursos vegetales en Mexico (Palomino, G., ed.). Jardín Botánico, Univ. Nal. Autón. Mexico, Mexico, pp. 11-36.

Lacadena, J.R. (1988). Genética. A.G.E.S.A. (4a. de.), Madrid, España.

Martínez, J. and Palomino, G. (1996). Karyotype analysis in three new species of Echeandia (Liliaceae) and cytotypes of E. reflexa. Cytologia 61:215-223.

Martínez, J. and Palomino, G. (1997). Evidence of heterozygous chromosome interchange and chromatide exchange in autotetraploid cytotype of Gibasis schiedeana (Tradescantieae-Commelinaceae). Cytologia 62: 275-281.

Mercado,P., Ramamoorthy, T.P. and Palomino, G. (1989). Karyotypes of five Mexican species of Salvia subgenus Calosphace (Lamiaceae). Cytologia 54: 605-608.
Murashige, T. and Skoog, F. (1962). A revised medium for rapid growth and bioassays with tobacco tissue culture. Physiol. Plant. 5: 473-497.

Palomino, G. (1991). La importancia del enfoque interdisciplinario en el conocimiento de los recursos vegetales de Mexico. In: Avances en el estudio de los recursos fitogenéticos de Mexico (Ortega, R., Palomino, G.H., Castillo, F.G., González, V.A.H. and Livera, M.M., eds.). SOMEFI, Chapingo, Mexico, pp. 63-82.

Palomino, G. and Martínez, J. (1994). Cytotypes and meiotic behavior in Mexican populations of three species of Echeandia (Liliaceae). Cytologia 59: 295-304.

Palomino, G. and Vázquez, R. (1991). Cytogenetic studies in Mexican populations of Crotalaria L. (Leguminosae-Papilionoideae). Cytologia 56: 343-351.

Palomino, G., Mercado, P. and Ramamoorthy, T.P. (1986). Chromosomes of Salvia subgenus Calosphace (Lamiaceae) - a preliminar report. Cytologia 51:381-386.

Palomino, G., Viveros, R. and Bye, R. (1988a). Cytology of five Mexican species of Datura (Solanaceae). Southwest. Nat. 33: 85-90.

Palomino, G., Zuleta, S.L. and Sheinvar, L. (1988b). Estudios citogenéticos de dos especies y una variedad del género Nyctocereus (Cactaceae). Bol. Soc. Bot. Mex. 48: 75-80.

Palomino, G., Segura, M.D., Bye, R. and Mercado, P. (1990). Cytogenetic distinction between Teloxys and Chenopodium (Chenopodiaceae). Southwest. Nat. 35: 351-353.

Palomino, G., Martínez, P., Bernal, C. and Sousa, M.S. (1993). Diferencias cromosómicas entre algunas especies de los géneros Sophora L. and Styphnolobium Schott. Ann. MO Bot. Gard. 80: 284-290.

Palomino, G., Romo, G. and Zárate, S. (1995). Chromosome numbers and DNA content in some taxa of Leucaena (Fabaceae-Mimosoideae). Cytologia 60: 111-117.

Palomino, G., Dolezel, J., Cid, R., Brunner, I., Méndez, I. and Rubluo, A. (1999). Nuclear genome stability of Mammillaria san-angelensis (Cactaceae) regenerants induced by auxins in long-term in vitro culture. Plant Sci. 141: 191-200.

Price, H.J. (1988). DNA content variation among higher plants. Ann. MO Bot. Gard. 75: 1248-1257.

Price, H.J., Chambers, K.L. and Bachmann, K. (1981a). Genome size variation in diploid Microseris bigelovii (Asteraceae). Bot. Gaz. 42: 156-159.

Price, H.J., Chambers, K.L. and Bachmann, K. (1981b). Geographic and ecological distribution of genomic DNA content variation in Microseris douglasii (Asteraceae). Bot. Gaz. 42: 415-426.

Rubluo, A., Chávez, V.M., Martínez, P.A. and Martínez-Vázquez, O. (1993). Strategies for the recovery of endangered orchids and cacti through in vitro culture. Biol. Conserv. 63: 163-169.

Russell, P.J. (1992). Genetics. 3rd edn. Harper Collins Publishers, New York, USA.

Rzedowski, J. (1991). El endemismo en la flora fanerogámica Mexicana: Una apreciación analítica preliminar. Acta Bot. Mex. 15: 47-64.

Rzedowski, J. (1998). Diversidad y orígenes de la flora fanerogámica de Mexico. In: Diversidad Biológica de Mexico, Orígenes y Distribución (Ramamoorthy, T.P., Bye, R., Lot, A. and Fa, J., eds.). Instituto de Biología, Univ. Nal. Autón, Mexico, Mexico, pp. 129-145.

Zárate, S. (1994). Revisión del género Leucaena Benth. Ann. Inst. Biol. Univ. Nac. Autón. Mexico. Ser. Bot. 65: 83-112.

Zohary, D. (1970). Centers of diversity and centers of origin. In: Genetic Resources in Plants. Their Exploration and Conservation (Frankel, O.H. and Bennett, E., eds.). Blackwell Scientific Publ., Oxford and Edinburg, pp. 33-41. 